\title{
AN ANALYSIS OF SEMIOTIC RIFFATERRE IN WALT WHITMAN SELECTED POEM
}

\author{
Rusmitha Sipahutar ${ }^{1}$ \\ Universitas Putera Batam(UPB), Batam, Indonesia \\ Pb151210112@upbatam.ac.id \\ Tomi Arianto ${ }^{2}$ \\ Universitas Putera Batam(UPB), Batam, Indonesia \\ tomi.arianto@puterabatam.ac.id
}

\begin{abstract}
The object research in the Walt whitman poem was an Semiotic analysis seen from Michael Riffaterre's theory. This research used the descriptive qualitative method for this research. That means the method of data collection by analyzing and interpreting also described to understand the theories contained in the poem. In this qualitative research, researcher used the Semiotic theory by Michael Riffaterre in his book Semiotic of poetry as a basic concept and framework of thinking. The concept contains three point: The first was unsustainability of expression in poetry include the displacing meaning, distorting meaning, and the creating of meaning. It discussed the figurative language such as metaphor, personification and also the structure of verse. The second was Heuristic and Hermeneutic reading that has a relation with reading a verse based on language convension and overall rereading with interpretation. The last was Matrix, model, and varian is key,transformation, and description in a poem. In the Walt whitman selected poem finds some point based on the result of the analysis the data. From an analysis, the researcher concluded the dominant point in the Walt whitman poem is unsustainability of expression in poetry.
\end{abstract}

Keywords: Semiotic, poem, Walt Whitman

\section{INTRODUCTION}

Kinds of the medium of literary works such as, novel, poem, essay, short story, drama, and fiction have been invented by writers to serve their needs and to express their idea. One of the medium of literary works is poem. According to Ahmad (2006) poem is any kind of verbal or written language that is structured rhythmically totell a story, or express any kind of emotion, idea, or heart condition. Poem its self is arranged in lines and poem also describes as a various kind of spoken and written forms, styles, and patterns, and also a various kind of subjects.
According to Anindita \& Satoto (2017) stated that poem is indirect ex pression, meaning that is describes omething by using connotative meaning. Then indirect expression ca use by displacing of meaning, distorti ng of meaning and creating of meani ng. So, to know the real understandin $\mathrm{g}$ of the poem is to read it repeatedly and embrace the ambiguity. When $\mathrm{w}$ e read a poem, sometimes we find th e difficulties in appreciate and in find ing out the meaning. If we do not know the meaning of poem, we cannot understand the whole meanin $\mathrm{g}$ of a poem.

The poem that the researcher would like to analyze is literary 
works by Walt Whitman. He was born in West Hill, New York on May 30, 1819 and died in Camden, New Jersey on March 26, 1892. Walt Whitman was an American poet, essayist, and journalist. Walt Whitman was the most influential poets in the American, often called the father of free verse. In this paper, the researcher would like to analyze the literary work of Walt Whitman. The entitle is O Captain, My Captain and I hear America singing. Both of poem will analyzed using semiotic theory by Michael Rifaterre and the researcher will interpreted the meaning of the poem.

There are journals that give much the inspiration in developing ideas in this research. The first journal is Husain (2014) entitled "Semiotics analysis in William Blake poems" This research focused on semiotic of Riffaterre's theory in William Blake poems, titled The Sick Rose, My Pretty Rose Tree, and The Garden of Love. The method that used in this research was descriptive qualitative method. The data that used in this research was a written record in the form of three poems by William Blake. The technique used to collect data in this research was the technique of reading log. The researcher used the Riffaterre's theory to analysis the poems. In research, it is so important for every researcher to specify their method of research. The researcher tries to focus and discuss research design, the object of the research, the method of collecting data, the method of analyzing data, and the method presenting research result.

The journal discuss about semiotic analysis in William Blake poem using Rifaterre's theory same with this research. Based on the journal above the researcher take the conclusion that there are four part of Riffaterre's theory to produce of poem's meaning the first is unsustainibility expression of the poem include displacing of meaning, distorsing of meaning, and creating of meaning, the second is heuristic and hermeneutic reading, the third is matrix, model, varian and the last is hypogram.

\section{REVIEW OF RELATED LITERATURE}

2.1 Riffaterre's Semiotics of Poetry Semiotic come from Greek language the word semiology means interpretation that talk about sign. There so many expert who stated semiotic but this researh would analize of Riffaterre's theory. The emphasis of Michael Riffaterre's theory in relation with literary work is the understanding meaning of the literary work itself through sign. In fact, language is a sign system and language itself is the literary media. Whole the text in the literary works is a sign that have to interpreted to know the better understanding of the text. Ratih (2016: p.5)

This research using semiotic theory that developed by Michael Riffaterrre. Generally, theory of Riffaterre (2009 p.3) in his book entitled Semiotic of poetry propose four point in understanding and interprated a poem. The first is unsustainibility expression of poetry it means tha literary works stated something with other meaning. There are three cause of unsustainibility expression of poetry namely displacing of meaning, distorsing of 
meaning, and creating of meaning. Displacing of meaning happen when a sign have a change from one meaning to the other meaning. Generally the application of figurative language such as metaphor, personification, and metonimy. Distorsing of meaning or deviation of meaning happen because of ambiguity, contradiction, and non sense. Ambiguity is a word, pharase, or sentence that have a different interpretation in meaning context. Contradiction is a using of irony, paradox, and antitesis. Nonsense is a words that has magical meaning in context. Creating of meaning is interpretation to meaningless language such as is rhyme, symmetrical and homolog in stanza. Example of creating meaning is enjambement, typografi, and homolog.

The second is Heuristic and hermeunitic Reading. In this theory, Heuritic reading is a first stage of interpretation. In this stage the reader know the structure of whole literary work. While hermenetic is the second stage of interpretation, it means the reader combine with the first stage reading and understand all the interpretation in the first stage reading such as ungrammatical. The third is matrix, model and varian and the last is hypogram or intertextual relation.

\subsubsection{Displacing Meaning According Keraf}

p.138- 142) displacing of meaning happen when a sign have a change from one meaning to the other meaning. Generally the application of figurative language such as metaphor, personification, and metonimy.

\subsubsection{Distorting Meaning}

Riffaterre (as cited in Pradopo 2010 p.213) satated that distorsing of meaning or deviation of meaning happen because of ambiguity, contradiction, and non sense. Ambiguity is a word, pharase, or sentence that have a different interpretation in meaning context. Contradiction is a using of irony, paradox, and antitesis. Nonsense is a words that has magical meaning in context.

\subsubsection{Creating Meaning}

Riffaterre (as cited in Pradopo 2010 p.220) stated that creating of meaning is interpretation to meaningless language such as is rhyme, symmetrical and homolog in stanza. Example of creating meaning is enjambement, typografi, and homolog.

2.1.4 Heuristic and Hermeneutic In this theory of Pradopo (2010 p.295) Heuritic reading is a first stage of interpretation. In this stage the reader know the structure of whole literary work also change the poem language into common language with clear interpretation so that the reader easy to understand the meaning of the poem. While hermeneutic is rereading of the poem the second stage of interpretation meaning, it means the reader combine with the first stage reading and understand all the interpretation in the first stage reading such as ungrammatical. Pradopo (2010 p.297)

\subsubsection{Matrix, Models and Variants} According Pradopo (2010

p.299) Matrix is a keyword that found in poem and become a key of verse interpretation that concretized. 
Model is transformation of matrix. Varian is a problem and description in a poem.

\subsubsection{Hypogram: Intertextual Relations}

Hypogram is about intertextual relation, that have two part. The first is Potential and actual hypogram. Potential hypogram is implication of language meaning, and actual hypogram is a good response include pros and cons in text of poem itself. Meaning can be found through various forms of objectivity in the form of text. However, the text that becomes the matrix or the hypogram itself can only be found after finding the meaning of the language of the poem in question. The meaning of the language is a referential meaning in the form of a series of unramatically (ungramatically), namely the differential between the linguistic sign units in the text and the description of the reality they refer to. Because this meaning is linguistic, it can be found in poetry texts that are examined or read. It's just that the units of linguistic meaning itself are inadequate to bring the reader to the knowledge of "meaning" but only to be "introductory" towards him. The units of linguistic meaning, which are in the form of a series of irregularities, must be connected with each other in opposition so as to form opposing pairs which are mutually equivalent and

paradigmatic. To form these paradigmatic oppositional pairs, the reader must make a hermeneutic reading and read with the help of "literary conventions". Literary conventions function to find the possibilities of symbolic meanings which can bring together the linguistic meaning units with each other, to transcend gradually the existing set of irregularities (Faruk, 2012: 148).

\subsection{Previous Research}

There are some journals and research that give a lot of the inspiration and development ideas in this research. The first journal is Husain (2014) with entitled "Semiotics analysis in William Blake poems" This research focused on semiotic of Riffaterre's theory in William Blake poems, titled The Sick Rose, My Pretty Rose Tree, and The Garden of Love. The method that used in this research was descriptive qualitative method. The data that used in this research was a written record in the form of three poems by William Blake. The technique used to collect data in this research was the technique of reading log. The researcher used the Riffaterre's theory to analysis the poems. In research, it is so important for every researcher to specify their method of research. The researcher tries to focus and discuss research design, the object of the research, the method of collecting data, the method of analyzing data, and the method presenting research result.

The second journal was conduscted by Ridwan (2013) with entitled "an analysis semiotic in the novel Poison by Sara Poolo. This thesis is a research about analysis semiotic in the Novel "Poison" By Sara Poole. The objective of this research are to know the meaning of Poison in novel by semiotic approach. The method used in this reseach is qualitative method. The 
object of this reseach used both formal and material object. Formally, this reseach used semiotic by using Rolland Barthes theory. Materially this reseach used the novel Poison by Sara Poole. which was published in 2010 and some books was used to analyze and supported this research. In collecting the data, the writer used note taking as instrument. The writer used Riffaterre's theory to analysis semiotic in the Novel "Poison" By Sara Poole.

The third journal was conducted by Santoso (2019) with entitled "Analisis Semiotika Puisi Yogorecchimatta Kanashimini Karya Nakahara Chuya" The approach used in this research is the Riffatere's poetry semiotics with the concern in the analysis of heuistic and hermeneutic reading; analysis of unsustainable expressions; analysis of matrices, model and variants. The analysis result of heuristic and hermeneutic readings indicate that the poetry of Yogorecchimatta kanashimini poem describes the condition of poet's soul. He was afflicted with sadness that made him desperate, helpless and haunted by the fear. Indirect expression occurs through meaning substitution in form of metaphorical use, deviation meaning through ambiguity, and creation of meaning through asonance and repetition of lines.

The last journal was conducted by Arfan (2013) with entitled "analisis semiotika Riffaterre dalam puisi das theater, statte der traume karya Bertolt brecht" The purpose of this research is describe hermeneutic and heuristic reading, displacing meaning, distorting meaning, and creating of meaning of das theater statte der traume.

Refers to the journal above, the similarities between the journal above with this research is about the object of the data is poem and each using the same theory of Michael Riffaterre.

\section{METHOD OF THE RESEARCH}

3.1. Research Design

Research design is a framework which the researcher focuses to make the outline and details of each research procedure begin from the question to research problems to data that want to analysis.While analyzing the novel, the researcher uses descriptive qualitative research. According to Anderson, Adey, \& Bevan (2010) qualitative descriptive research typically involves fieldwork in which the researcher observes and records behavior and events in their natural setting. Thus, the research used qualitative method in analysing this research. This type of research data is a text taken from two data sources: primary data sources and secondary data sources.

3.2 Object of the Research

In this study, the main object is a Semiotic anlysis in the Walt Whitman Poem. This novel talks about the sign that includes in the poem and the sign that also found in real life.

3.3 Method of collecting data

In analyzing the novel, the researcher used the method of collecting data. Accoding to Sudaryanto cited in Dianto (2018) there are two kinds of techniques in collecting data: those are 
participatory, and non participatory. For this research, the research use the non participatory technique.

1. In the first procedure the researcher collects the main sources of the data which is $\mathrm{O}$ Captain, my captain and I hear America singing. The technique is used by gathering all the data from the library or from the internet and other supporting material relevant to the topic of this research as many as possible.

2. And then, the researcher begins to read the data carefully and takes the meaning of the semiotic.

3. Then, the researcher begins to take down notes and compose it properly.

4. The researcher also underlines every data like symbol that shows in the $\mathrm{O}$ Captain, my captain and I hear America singing to make it easier to collecting from the whole data.

5. The whole data, the quotation will be put in this thesis later on and find out the relations with the study. The right data are divided into parts to suit the parts of the study. All of the data are read carefully line by line to find out the relation with the study.

\subsection{Method of Analyzing Data}

According to Nyoman (2004)

the method of analysing the data has fucntion to explain connection the indication literaty work and theory. Another function to motivate or modify the idea of research. For this research, the researcher use the theory by Michael Riffaterre to analyze the Semiotic in the poem.

1. The researcher analyzed the data in the O Captain, my captain and I hear America singing poem.

2. The researcher combines important data from many sources that have been collected and analyzed them well.

3. The researcher also applies library research.

4. The writer analyzes the selected data.

5. Then, the researcher describes clearly the analysis.

6. And the last, the researcher concludes at the end of the analysis.

3.5 Method of Presenting Research Result

According to Sugiono (201

4) the most frequent form of displaying

data for qualitative descriptive metho ds. Data regarding qualitative, intended for research uses the words or paragraphs to convey the research. For this research, the researcher chooses the qualitative descriptive method because the researcher uses sentences and pharagrap to explain by explaining the result of study

\section{Result and Discussion}

\subsection{Semiotic Riffaterre}

Micahael Riffaterre in his book entitled Semiotics of poetry, stated that there are 4 thing that must be understand to know the meaning of a poem. The first is unsustainability of expression in poetry include the displacing meaning, distorsing meaning and the 
creating of meaning. The second is Heuristic and Hermeneutic reading, matrix, model, varian, and hypogram.

4.2 Unsustainability of expression in poetry

\subsubsection{Displacing of meaning}

Displacing meaning is a change in the meaning of the words in a poem that does not use the actual meaning. Usually poetry like that uses Figurative language. Figurative language used in the replacement of meaning are personafication and metaphor.

\subsubsection{Metaphor}

In the first poem entitle $\mathrm{O}$ Captain, My Captain there are 2 metaphor. The first is the word

"Captain". Here Captain means Abraham Licoln who loses his life in the battle. The second metaphor is "Voyage" which present the civil war. In the second poem entitle I hear America singing there is "Varied Carol" which present worship song.

\subsubsection{Personification}

In the first poem entitle $\mathrm{O}$ Captain My Captain Whitman has used personification to give human qualities to lifeless objects. He has personified the walk of the speaker as a "mournful tread" because he cannot live without his captain. He has also personified shores where it is stated, "Exult, O Shores!" As if the shores are humans and they are going to blow trumpets of victory. The second poem entitle I hear America Singing there is word "America singing" it was personification, because America, th e actual landmass, cannot sing. As de finition of personification giving human char acteristics to nonhuman things.

4.2.2 Distorting meaning

Riffaterre stated that distorting meaning include the ambiguity, contradiction, and nonsense.

\subsubsection{Ambiguity}

Ambiguity is a sentence that have a double meaning. In the first poem entitle O Captain My captain there is ambiguity "For you they call, the swaying mass, their eager faces turning" the word the not explain that their indicate for who. In the second poem entitle I hear America Singing is the word "the delicious singing of the mother" in this sentence of the poem is ambiguity because delicious is usully refers to food but in this poem refers to melodious.

\subsubsection{Contradiction}

Contradiction is the contradiction between two things caused by paradox. In the first poem entitle O Captain, My Captain there is contradiction in the last line. "Fallen cold and dead." in this line describe the speaker of the poem feel two condition condition, fallen cold and dead because walk the deck their captain lies. In the second poem entitle I hear America Singing is "Those of mechanics, each one singing his as it should be blithe and strong" in this line the speaker of the poem feel two condition too, blithe and strong. The mechanics singing with blithe and strong. 
4.2.3. Creating of meaning

Creating of meaning is caused by organizing of text include enjambement, verse, typography and homolog.

\subsubsection{Enjambement}

Skipping lines in rhymes, make the meaning intensity in the last word skip to the next line. In the first poem entitle O Captain My Captain there is enjambement.

Where on the deck my Captain lies, Fallen cold and dead.

The quotation of the poem is enjambement, because with enjambement there is an emphasize of the meaning. With enjambemen the quotation become "Where on the deck my Captain lies, Fallen cold and dead."

In the second poem entitle I hear America song also have enjambent.

The day what belongs to the day at night the party of young fellows, robust, friendly, Singing with open mouths their strong melodious songs.

With enjambent the quotation of the poem become The day what belongs to the day at night the party of young fellows, robust, friendly, Singing with open mouths their strong melodious songs.

\subsubsection{Verse}

The first poem entitle "O Captain My Captain" it follows a rhyme scheme of AABBCDED.It is the only Walt Whitman poem that follows a regular meter and rhyme scheme. Walt Whitman wrote several free verse poems (he was nicknamed "Father of Free verse"), but "O Captain! My Captain!" is the exception.
O Captain! my Captain! our fearful trip is done,

The ship has weather'd every rack, the prize we sought is won,

The port is near, the bells I hear, the people all exulting,

While follow eyes the steady keel, the vessel grim and daring;

But $O$ heart! heart! heart!

$O$ the bleeding drops of red,

Where on the deck my Captain lies,

Fallen cold and dead.

"I Hear America Singing" This poem is not written according to formal poetry rules; such as end rhyme employed or blank verse (unrhymed iambic pentameter) the structure upon which the poem is built. Instead, Walt Whitman writes in free verse a looser form of poetry, which is not subject to strict meter, rhyme, and stanzas. One example of this stricter, more formal poetry would be a Shakespearean sonnet.Free verse does not have regular patterns or arrangements of rhyme and meter. Walt Whitman does not use numerous stanzas in this either.

I hear America singing, the varied carols I hear,

Those of mechanics, each one singing his as it should be blithe and strong, The carpenter singing his as he measures his plank or beam,

The mason singing his as he makes ready for work, or leaves off work, The boatman singing what belongs to him in his boat, the deckhand singing on the steamboat deck, The shoemaker singing as he sits on his bench, the hatter 
singing as he stands,

The wood-cutter's song, the ploughboy's on his way in the morning, or at noon intermission or at sundown, The delicious singing of the mother, or of the young wife at work, or of the girl sewing or washing,

Each singing what belongs to him or her and to none else, The day what belongs to the day-at night the party of young fellows, robust, friendly,

Singing with open mouths their strong melodious songs.

4.3 Heuristic and Hermeneutic reading

\subsubsection{Heuristic Reading}

In reading heuristic, verse is read base on language convension or language system semiotic in first stage. This is The heuristic reading of the first poem entitle "I hear America singing" by walt whitman.

I hear America singing, the varied carols I hear,

( I hear the various American Christmas song)

Those of mechanics, each one singing his as it should be blithe and strong, (Each mechanic sing it with joy and louder)

The carpenter singing his as he measures his plank or beam, (The carpenter singing while measure his plank or beam)

The mason singing his as he makes ready for work, or leaves off work (The mason singing when he go to work and after back from work)

The boatman singing what belongs to him in his boat, the deckhand singing on the steamboat deck,

(The boatman singing whatever he has in his boat, the deckhand singing on the steamboat deck)

The shoemaker singing as he sits on his bench, the hatter singing as he stands, (The shoemaker singing in his sits, the hatter singing when he stands)

The wood-cutter's song, the ploughboy's on his way in the morning, or at noon intermission or at sundown,

( The wood-cutter's song, the ploughboy's on his way in the morning or when break or on sunset.) The delicious singing of the mother, or of the young wife at work, or of the girl sewing or washing ( The melodious singing of mother or or of the young wife at work, or of the girl sewing or washing)

Each singing what belongs to him or her and to none else,

( Each singing whatever he has, does not belong to anyone)

The day what belongs to the day at night the party of young fellows, robust, friendly, (The day what belongs to the day at night the party of young, robust, friendly,) Singing with open mouths their strong melodious songs.

(Singing with open mouth and their strong melodious songs)

Heuristic reading of the third poem entitle O Captain My Captain

O Captain! my Captain! our fearful trip is done, (O captain my Captain! Our afraid jorney is done) 
The ship has weather'd every rack, the prize we sought is won,

(The ship through much obstacle, the dream had been in grip)

The port is near, the bells I hear, the people all exulting,

(The port had beeen near, $i$ hear the bell and the people having fun)

While follow eyes the steady keel, the vessel grim and daring;

(While the eyes follow the sturdy keel, my ship frowned gallantly)

But $O$ heart! heart! heart!

(But oh my heart,heart!)

$O$ the bleeding drops of red,

(O bloody reddish drops,)

Where on the deck my Captain lies,

(On the deck my Captain lay)

Fallen cold and dead.

(Lifeless cold)

$O$ Captain! my Captain! rise up and hear the bells;

(O Captain! You are my Captain! get up and hear the bell)

Rise up-for you the flag is flung-for you the bugle trills,

(Rise up, for you the flag is fluttering, for you trumpet blares)

For you bouquets and ribbon'd wreaths-for you the shores a-crowding, (For you banded coral bouquets, for you this crowded beach)

For you they call, the swaying mass,

their eager faces turning;

(For you they exclaim, the crowd is

boisterous, all looking for you)

Here Captain! dear father!

(Come here Captain! My beloved

father!)

This arm beneath your head!

(Let my arms carry your head)

It is some dream that on the deck,

(As if in a dream, you are on this deck,)

You've fallen cold and dead.

(Sprawling lifeless cold)

My Captain does not answer, his lips are pale and still,

(My captain did not answer, his lips pale and frozen)
My father does not feel my arm, he has no pulse nor will,

(My father could not feel my arm, no pulse, no will)

The ship is anchor'd safe and sound, its voyage closed and done,

(Sauh telah dilepas, pelayarannya telah usai)

Frkom fearful trip the victor ship comes in with object won;

(After the death journey, the ship has triumphed, dreams have been anchored)

Exult $O$ shores, and ring $O$

bells!

(Rejoice, all the beaches, all together, all the bells!)

But I with mournful tread, (As for me, with sad

steps)

Captain lies,

$$
\text { Walk the deck my }
$$

Captain lay, )

$$
\text { (On the deck my }
$$

Fallen cold and dead. (Lifeless cold)

4.3.2 Hermeneutic Reading

Hermeneutic reading is overall rereading with interpretation. In the first poem entitle Singing Ihear America The poet hear the various carol America song. The mechanic, the carpenter, the mason, the hatter, the boatman, the shoemaker and all people also singing the song with joy and louder voice. The writer also hear the melodious song of American people singing while they do their activity until they finish their work and the sun is set. They are very happy and joy. In the second poem entitle $\mathrm{O}$ Captain My Captain is the first stanza is telling about a long jornay that had been done and dream had been in hold but the poet feels 
sadness because his captain passed away after a long afraid jorney.

\subsection{Matrix, model, and Varian}

\subsubsection{Matrix}

Matrix is a keyword that found in poem and become a key of verse interpretation that concretized. In the first poem entitle $\mathrm{O}$ captain $\mathrm{My}$ captain matrix of the poem is the poet refers to the fallen captain as "father," representing his deep respect for president Lincoln and Lincoln's role as father of the Union. Matrix of the second poem "I hear American song" is happiness condition of the poem hearing of America Singing. In "I Hear America Singing," the poet describes various "carols" that arise from different figures in the American working class as people go about their work. $\mathrm{He}$ hears the mechanics, the carpenter, the mason, and the boatman singing. The deckhand, shoemaker, hatter, wood-cutter, and ploughboy sing their own songs, as well.

\subsubsection{Model}

Model is transformation of matrix. In the first poem entitle O Captain My Captain is sadness and grief because of left by his captain or father. Model in the second poem entitle I hear America Singing is happiness, joy, and blithe.

\subsubsection{Varian}

Varian is a problem and description in a poem. In the first poem entitle $\mathrm{O}$
Captain My Captain is the first varian is describe deep sadness of the poem to the Abraham Licoln which lay stiff. The second varian is a grief feeling because know his captain passed away. In the second poem entitle I hear America Singing. The first varian is describes various "carols" that arise from different figures in the American working class as people go about their work.

\section{CONCLUSION}

After analyzing of semiotic of Michael Riffaterre by Walt whitman poem entitled O, Captain My Captain and I hear American song there are three of point in the semiotic. The first is Unsustainability of expression in poetry include the displacing meaning, distorting meaning, and the creating of meaning. It discuss the figurative language such as metaphor, personification and also the structure of verse. The second is Heuristic and Hermeneutic reading that has a relation with reading a verse based on language co nvension and overall rereading with $i$ nterpretation. The last is Matrix, model, and varian is key,transformation, and description in a poem.

\section{REFERENCES}

Adudu, H. H., \& Husain, D. (2014) Semiotic analysis in william blake poems, British Jurnal bahasa dan sastra inggris vol. 01 (2014) 77-78

Ahmad, J., \& No, Y. (2006). Imagery in Langston Hughe's poetry, Jurnal 
Imiah Bina BAHASA Vol.5 No2, Desember 2012: 103 - 114

Anderson, J., Adey, P., \& Bevan, P. (2010). Positioning place: Polylogic approaches to research methodology. Qualitative Research, 10(5), 589604.

https://doi.org/10.1177/14687941103 75796

Anindita, K. A., \& Satoto, S. (2017). Diction in Poetry Anthology Surat Sugiyono. (2014). Metode Penelitian Pendidikan Pendekatan Kuantitatif, Kualitatif dan R\&D. Metode Penelitian Pendidikan Pendekatan Kuantitatif, Kualitatif Dan $R \& D$. https://doi.org/10.1007/s13398-0140173-7.2

Ratih, Rina. (2016). Teori dan Aplikasi Semiotik Michael Riffaterre. Yogyakarta: Pustaka Pelajar.

Santoso (2019) Analisis Semiotika Puisi Yogorecchimatta Kanashimini Karya Nakahara Chuya. Japanese Research on Linguistics, Literature, and Culture

Vol. 1 No. 2 May 2019 154-166 DOI : 10.33633/jr.v1i2.2501

Arfan (2013) analisis semiotika Riffaterre dalam puisi das theater, statte der traume karya Bertolt brecht. Majalah Horison Jakarta vol.2 (2004)

Sudaryanto cited in Dianto (2018) Understanding Participatory Action Research: A Qualitative Research Methodology Option. Canadian Journal of Action ResearchVolume 13, Issue 2, 2012, pages 34-50
Kopi by Joko Pinurbo as A Poetry Writing Teaching Material, International Journal of Active Learning 02 (2017), 39-49.

Keraf, Gorys. (2009). Diksi dan Gaya Bahasa. Jakarta: Gramedia Pustaka Utama

Ridwan, I. N., \& Faculty, H. (2013). Analysis Semiotic in the Novel " Poisos " by Sara Poole, (40300109101).

Pradopo, Rachmat Djoko. 2010. Pengkajian Puisi. Yogyakarta: Gadjah Mada University Press. 